\title{
Fostering Students' Critical Reading Through Digital Short Story Trailer Project
}

\author{
Sophia Fithri Al-Munawwarah", ${ }^{1, *}$ Gin Gin Gustine ${ }^{2}$, Bachrudin Musthafa $^{3}$ \\ Universitas Pendidikan Indonesia \\ *Corresponding author. Email: sophiafithri@upi.edu
}

\begin{abstract}
Literacy teaching by utilizing technology is not a new yet has been well-developed in numerous studies. In order to augment this growing topic, the present study delineated EFL students experience in interpreting the content of English texts and reviewed the texts through video trailer. This article juxtaposed the students' engagement in teaching literacy through digital short story trailers as a result of promoting students' critical literacy. Questions that require higher order thinking skills were posed to encourage students' critical literacy in reading short stories. The data of this descriptive study were gathered from observations and interviews with eleventh undergraduate students who were voluntarily involved in this research. The gathered data attested that students were engaged, worked cooperatively, and successfully produced short story trailer that not only summarized the texts but also included their point of view about the text. Moreover, the participants also uttered that they found an interesting way to show their understanding of the given stories. The evidence suggests that EFL teachers may guide students by using critical questions to make digital short story trailers in order to entice them to read texts critically.
\end{abstract}

Keywords: Critical reading, digital short story, EFL students

\section{INTRODUCTION}

In foreign language teaching, reading critically can be seen as a major goal of the learning process and considered as a crucial part of learners' reading proficiency in the $21^{\text {st }}$-century learning (Emilia, 2010; Erikson \& Erikson, 2019; Indah, 2016; Kumagai \& Iwasaki, 2011). Hence, the way in assisting learners to be critical readers become a major concern in EFL classroom. In connection with this, it is a challenge for teachers to build critical reading activity as a fun classroom project by utilizing appropriate strategy (Wallace \& Wray, 2016). Since technology evolves in students' everyday lives, incorporating ICT and language learning should be a great idea.

Critical literacy can be defined as the use of texts to analyze and transform relations of cultural, social, and political power (Jones, 2013). When people are critically literate, they examine their ongoing development in order to show the subjective positions from which people make sense of the world and act in it (Shor, 1999). Seeing this, it can be said that critical literacy can be seen as decontextualized skills that can be applied in any situation. Besides, the value of critical literacy fits to language teaching.

Dealing with this, there are few studies which deal with critical literacy in English as foreign language teaching. Dealing with this, in terms of orientation to critical literacy on English as an additional language, a study undertaken by Alford \& Jetnikoff (2016) focuses on portraying the ways four EFL teachers of senior English constructed critical literacy in their talk and practice. The research was conducted in two state high schools in Queensland. It was a case study, and the data were gathered by utilizing Janks' (2000) model of critical literacy (covering domination, access, diversity, and design), interview, and video recordings of teachers' classroom practice. The data reveals that the teachers' understanding varied. It indicates the teachers' 
commitment to critical literacy as an approach to English language teaching.

In terms of teaching reading with critical attitudes, another study conducted by Dar, Rahimi \& Shams (2010) tried to examine the importance of developing learners' critical language awareness through some techniques of CDA. Sixty students were participated in the study. This study showed that CDA techniques enhance students' critical language awareness. Another study carried out by Gustine (2018) aimed at exploring the meaning of literacy for in-service English teachers as well as strategies to help students develop their critical literacy and what English teacher know about critical literacy as pedagogical model. It is a survey study with 21 English teachers in Bandung as the sample in responding the questionnaire. The data showed that some teachers show lack of knowledge on critical literacy as methodological approach to teaching English. In addition, a research carried out by Kurniawati (2016) aimed at examining the use of critical literacy (CL) program in a critical reading course at one university in Indonesia. This is a case study. through this study, the data revealed that the implementation of infusing CL program in reading course was successful.

Given this, it is highlighted that in EFL context, critical literacy by integrating digital literacy has not been widely investigated. In Asian setting, this area of research commonly has been conducted at tertiary level. Besides, there is no previous research that tries to identify the relationships between critical literacy-based teaching with students' digital literacy. Hence, in order to fill the gap, this study will relate critical reading activity and appropriate technology within the context of English as Foreign Language Learning. Likewise, in order to support the initiative to manage more challenging learning activity and to build freedom to learn and create democratic classroom as a public sphere (Giroux, 2009), in the language teaching, digital short story trailer project by utilizing technology can be one of the alternatives. With this in mind, having foreign language learners design short story trailer may encourage them to read and develop their creativity.

Apart from that, no doubt that appropriate technologies can be powerful language learning tools to meet certain learning outcomes. Hence, since $21^{\text {st }}$ century students have knowledge and experience in using digital tools, teaching literacy can be more interesting and relevant by combining critical reading activity and using technology during the learning process. Hence, this study aims at investigating the benefits of using technology to facilitate students in designing digital short story trailers as the result of their critical reading. By doing this, it is expected to spark the interest of students during the lessons. To entice them to learn, the present study tries to relate critical reading and technology assisted language learning to reach all students to read critically in English as a foreign language setting. Through this, it may drive novel innovations in critical literacy teaching. It is as stated by Gura (2014) that applying appropriate technology to literacy classroom may attract students' attention and participation.

\section{METHOD}

The aim of this research was to delineate the state of incorporating technology in literacy teaching within the context of EFL learning. Particularly, the present study tried to portray the students' engagement in critical reading course by using suitable technology. Besides, this study also focused on identifying students' attitude towards the learning activity. Hence, this study applied qualitative research design taking on characteristics of descriptive study. This is as stated by Nassaji (2015) that a descriptive study is organized in order to delineate the existing distribution of variables without regards to another hypothesis.

\subsection{Data collection}

\subsubsection{Sample and site}

The present study was administered at one public university in West Java. The project involved sixth semester eleventh students of the bachelor's degree in the Mathematic Education Major. They were four males and seven females. During the lesson, the researcher espoused as the teacher who guide the learning process. All of the participants were participated in observation session. Besides, the researcher solicited participants' perception on the learning process through interview. They were advised to respond given questions based on their angle. All participants agreed to release the data for research publication.

\subsection{Instrumentation}

Since the present study focuses on examining the benefits of utilizing video trailer apps in literacy teaching, there were two instruments utilized in this study; namely, semi structured interview and observation. Before conducting the research, the researcher had been informed about the objective of this present study. Furthermore, each technique in collecting the data will be described below. 


\subsubsection{Observation}

In addition, in carried out this research, observations were conducted nine times. each meeting was organized 90 minutes. During the lessons, guided questions adapted from some theoretical foundations including the fourdimensional model, Janks' model (2000), the Four Resources Model (Van Sluys, Lewison, \& Flint, 2006; Flint, Van Sluys \& Lewinon, 2003) and Discourse Historical Approach (DHA) developed by Reisigl and Wodak (cited in Wodak \& Meyer, 2009). was adopted to guide the students in order to notice the important points in creating book trailer. The following questions are; (1) who's character is heard in the story? (2) can you identify the writer's point of view? (3) what does the story want you to believe? (4) do you agree with the act/statement(s) utter by the character in the story? Why/why not. (5) can you relate the story to your own experience? and others.

During the lessons, students were asked to comprehend short stories and reframing the texts from critical reading perspective through video trailers. They were worked in group of three or four to plan the video through online discussion. In discussion session, participating in putting certain ideas is mandatory in this mission. Participants were asked to communicate with each other so that the students can keep track the information and ideas while discussing with their peers. Hence, participants who contribute useful and insightful ideas were identified through the conversation. Having the data from observations, in order to gain in depth data, the researcher organized the interview session. The findings during the observation session and interview are elaborated below.

\subsubsection{Interview}

To obtain further information related to the aim of the study and to ensure that the data obtained were accurate, the interview was conducted to all of participants. the respondents were allowed to use Bahasa Indonesia in stating their opinion in order to help the them in expressing their feelings more easily. In the interview session, the respondents were allowed to request for clarification when they found any questions that confused them.

\subsection{Data Analysis}

The data were analyzed and interpreted based on the information from the observations and interview. In analyzing the data from observation, the video of classroom observations was transcribed to see the real situation in the classroom. Besides, the field notes were employed in order to get detail comprehension of the learning activities. In analyzing the data, the researcher read the transcribed data so that the data could be analyzed and interpreted. Meanwhile, in analyzing the data from interview, the researcher transcribed the interview and analyzed the data by repeated reading and then interpreted them based on some relevant literature.

\section{FINDINGS AND DISCUSSION}

The reported data, drawn from online classroom observations, interview and the result of the students' works. The findings of the research confirm two things; first, teaching critical reading through guided critical questions in comprehending short stories were considered as the catalyst for EFL learners in developing their critical reading. It is in line with a research conducted by Nourdad, Masoudi \& Rahimali (2018) that questions that require higher order thinking skills help students in comprehending given text. In this present study, three short stories were used during the lessons; namely, Thank You Ma am by Langston Hughes; The Story of an Hour by Kate Chopin; and The Fun They Had by Isac Asimov. The stories were chosen by the students from researcher's virtual bookshelf as these texts can be classified as "easy to be read" by beginner readers and they content social values. Students were asked to read three short stories in different genres, discussing the content of the stories, giving their arguments about the content and associating their own experiences or their prior knowledge to the stories. In doing this, students were given questions starting from questions that can be categorized as lower order thinking skills (such as vocabulary recognition and basic information related to the content of the text) to higher order thinking skill. Besides, during the learning process, teacher and students practicing critical literacy in their talk.

Furthermore, as the final project, within small groups, they were asked to create two short story trailers as the result of their reading. The data of portraying critical reading activity and creating original short story trailers were garnered through multiple observations within nine class periods. The students were allowed to use any applications that creates video were utilized for this project.

The students were discussed the aforementioned questions in the small group of online discussion and told the results to others. In discussion session, sometimes, there were different interpretations of the given text. It may appear since they have different experiences in real life. By seeing this, it can be said that the discussion session became more interesting as the students made their own hypothesis based on their background 
knowledge and experience (Correia, 2006). For instance, while discussing "Thank You Ma'am" story where social issue was explored, the learners tried to relate the main character's experience, Mrs. Jones who showed unexpected act of kindness to the young man who tried to stole her bag, into their own opinions or experiences in the real life. The students' responses were varied. One of them uttered that the character of Mrs Jones changed their point of view in order to cope with that kind of situation. Meanwhile, the other said that it will never happened around his neighbourhood.

Likewise, posing critical questions before producing the short story trailer videos was also intended to promote students' critical literacy. These kinds of activities can be considered as discerning strategy. It is as uttered by the first participant. She states that "...actually, previously, I don't really like English course because the previous English class was little bit boring while I only have very limited opportunity to the language during the lesson...this course is different I think. It is more interesting since it is the first time I experience these kind of activity in learning English...." Besides, the second participant said that "...the activity was interesting. I felt enjoy during the discussion session. And, I like the teaching and learning process by using the given short stories since I like the content and the characters of the stories. Besides, I was excited in the process of making of the video too since there was guided questions given by the lecturer." Furthermore, the other participant also admitted that "...I think it's interesting way to read English text in the context of foreign language and it's a new way in learning foreign language since we can relate the content of the text with our own experience." Given this, it was apparent that the participants showed positive attitude toward the lessons. In connection with this finding, as mentioned previously, critical literacy has become one of major points in second and or foreign language teaching and learning process. This finding actually confirms the statement proposed by Barnett and Francis (2012) that higher order thinking questions is necessary to assist learners to foster their' critical thinking while reading a text.

Second, as mentioned previously, since the participants in this study can be considered as 'digital natives', hence it is suitable to utilize technology assisted language learning. Dealing with this, critical reading by integrating video maker applications aids the learners to engage the lesson and further to illustrate the stories to produce two videos as the result of their critical reading. It is as stated by Ko (2017) and Sung and Mayer (2013) that using suitable technology can make students pay more attention to the given task. The learners were asked to pitch the given short stories in order to make the reading activity more purposeful. In creating video story trailer project, there were some steps followed by the students, which were; they learnt the content of the story, generic structure of the text, drafted the summary of the text, jot down their review of the story. Afterwards, they utilized Filmora as convenient video maker apps afterwards uploaded the videos on You tube to entice other to read the stories. The students admitted that they used the same application in creating the video. Besides, they also utilized widely available information and technology that facilitated them to access photograph and music. Through this, it provides opportunity for them to tap into their prior knowledge of certain experience(s).

Having taught this kind of activity, learners were enthusiastic about attending the classes and creating their videos as the result of examining the texts. Furthermore, depicting the praxis of teaching literacy by utilizing suitable information and digital technology, it was proved that this activity-maintained pupils' engagement during a long lecture session. All of the participants were participated actively in both discussion session and creating the video. Moreover, it portrays that the use of appropriate technology was aimed at engaging students in literacy practices. In doing this, online discussion that was managed to talked about the video project between the members of the small groups can be considered worked since this kind of discussion was prominent to be utilized.

Dealing with the findings, with regard to disruptive era, teaching reading by utilizing critical literacy as pedagogical approach is demanding. With this in mind, posing critical literacy questions in pre-reading and postreading were considered helpful to develop students' reading skill. Dealing with this, posing critical literacy questions can be the alternative way to assist the students to understand the world (Dzakiah, 2020; Gustine, 2013; Jun-min, 2014). In this study, the world means that the condition as represented in the stories. Moreover, the data in this study was also in line with the statement proposed by Kurniawati (2016) that infusing critical literacy in reading course can enhance the quality of language teaching and learning process.

Apart from that, actually, numerous studies have investigated the use of information and communication technologies in second and/or foreign language classroom (Al-Munawwarah, 2015; Ghorbani \& Jahandar, 2015; Khoshnoud \& Karbalaei, 2015; Huang, 2015; Mei, Brown \& Teo, 2018; Naraghizadeh \& Barimani, 2013; Shokrpour, Mirshekari, \& Moslehi, 2019). In relation to this, in order to fill the gap, this study tried to relate ICTs and critical literacy study within the context of EFL classroom. Fortunately, based on the data gathered from observation and document analysis in the form of the 
content of the video, it is apparent that the technology applied in this present study was successful to entice students to learn and develop their reading skill.

Specifically, it is probably fair to say that designing short story trailer by using suitable application may promote students' critical reading. It is due to the reason in designing the video, the students combined the content of the story with some pictures and music that represent their interpretation. It is as can be seen in Figure 1 and Figure 2 as part of the video.

It can be seen clearly that the students utilized pictures provided in the internet. Besides, they also wrote their opinion about the content of the story that may attack other to read the text. However, there was a grammatical error which was commonly occurred in foreign language learning. Designing the short story trailer video can also be seen as the result of honouring students' idea in the reading activity. This finding is actually in line with the statement proposed by Lamer (2014) that this kind of project to develop their literacy skills. Moreover, the study is also in line with the statement proposes by Meyer and Forester (2015) that creating video project in language learning transforms learning experiences for learners in this digital age. Referring to the findings, particularly, the students were participated actively during the lesson and feel challenging in accomplishing the project. In addition, the short story trailer demonstrates their knowledge about the story. This finding confirms the statement proposed by Prins (2017) that appropriate digital tool affords new ways to develop students' critical literacy.

\section{CONCLUSION}

The present study espouses an integration of technology and literacy teaching. The data proves that literacy practice by integrating technology was challenging and fun for engaging students to learn the language and promoting their critical reading at the same time. All of the participants were viable in doing the video project. Through this research, it is hoped that the result of the present study can be one of the alternatives for EFL teachers to administer reading tasks. In addition, the findings of the present study points to challenges for critical reading within the context of EFL classroom to different level of education. In addition, there researcher notes that there is a limitation of the study since the researcher took part as a lecturer who applied the teaching procedure. Thus, to obtain more objectivity, the future study can be carried out in different method.

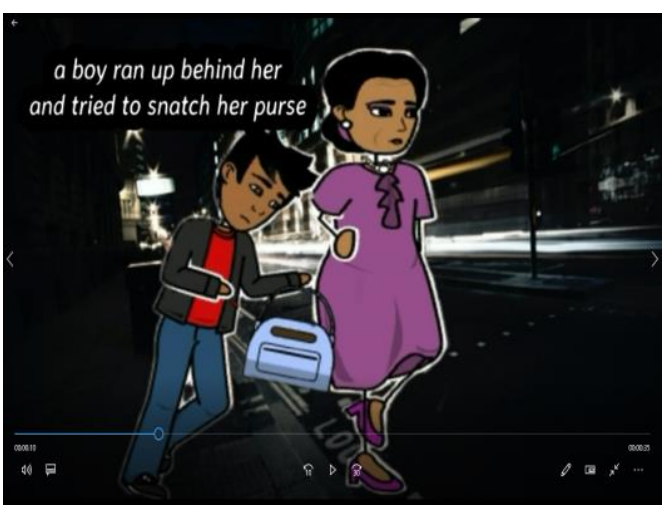

Figure 1 Students' assignment.

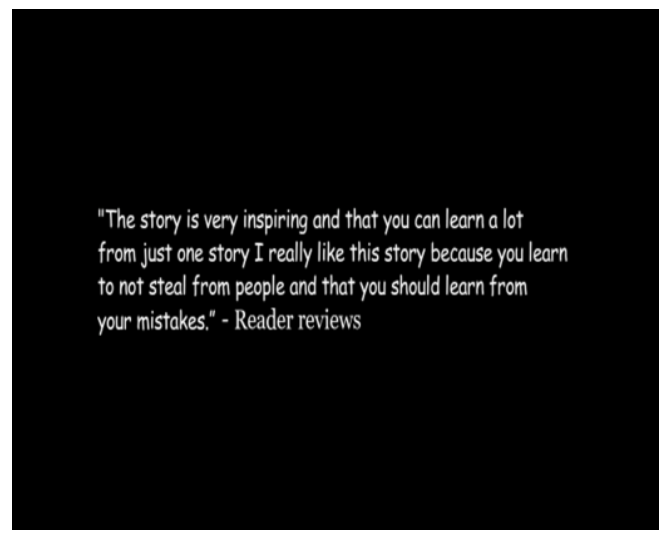

Figure 2 Students’ Assignment

\section{REFERENCES}

Alford, J., \& Jetnikoff, A. (2016). Orientations to critical literacy for English as an additional language or dialect (EAL/D) learners: A case study of four teachers of senior English. Australian Journal of Language and Literacy, The, 39(2), 111-125.

Al-Munawwarah, S. F. (2015). Teachers' perceptions on the use of ICT in Indonesian EFL learning context. English Review: Journal of English Education, 3(1), 70-80.

Barnett, J. E., \& Francis, A. L. (2012). Using higher order thinking questions to foster critical thinking: A classroom study. Educational Psychology, 32(2), 201-211. doi:10.1080/01443410.2011.638619

Correia, R. (2006). Encouraging critial reading in the EFL classroom. English Teaching Forum, 44(1), 16-19.

Dar, Z. K., Shams, M. R., \& Rahimi, A. (2010). Teaching reading with a critical attitude: Using critical 
discourse analysis (CDA) to raise EFL university students' critical language awareness (CLA). International Journal of Criminology and Sociological Theory, 3(2), 457-476.

Dzakiah, D. (2020). The Use of Higher Order Thinking Questions in Reading Comprehension to Improve the Students' Critical Thinking. Qalam: Jurnal Ilmu Kependidikan, 9(1), 36-42.

Emilia, E. (2010). Teaching writing: Developing critical learners. Bandung: Rizqi Press.

Erikson, M. G., \& Erikson, M. (2019). Learning outcomes and critical thinking-good intentions in conflict. Studies in Higher Education, 44(12), 22932303. doi: 10.1080/03075079.2018.1486813.

Flint, A., Van Sluys, K., \& Lewison, M. (2003). Disrupting the commonplace: Teachers researching critical literacy. School Talk, 8(4), 1-2.

Ghorbani, T., \& Jahandar, S. (2015). The Effect of Elearning on Iranian Intermediate EFL learners' word retention. International Research Journal of Applied and Basic Sciences, 9(7), 103-106.

Giroux, H. A. (2009). The attack on higher education and the necessity of critical pedagogy. In S. L. Macrine (Ed.), Critical pedagogy in uncertain times (pp. 1126), New York: Palgrave, Macmillan.

Gura, M. (Ed.). (2014). Teaching literacy in the digital age: Inspiration for all levels and literacies. USA: International Society for Technology in Education.

Gustine, G. G. (2013). Designing and implementing a critical literacy-based approach in an Indonesian EFL secondary school. International Journal of Indonesian Studies, 1(1), 2-21. Retrieved from https://arts.monash.edu/_data/assets/pdf_file/0011/ 1793603/1-Gin-Gin.pdf.

Gustine, G. G. (2018). A survey on critical literacy as a pedagogical approach to teaching English in Indonesia. Indonesian Journal of Applied Linguistics, 7(3), 531-537.

Huang, H. C. (2015). From web-based readers to voice bloggers: EFL learners' perspectives. Computer Assisted Language Learning, 28(2), 145-170.

Indah, R. N. (2016). Integrasi Berpikir Kritis dan Pembelajaran Bahasa Asing. In R. N. Indah (Ed.), Bunga Rampai Isu Kontemporer Bahasa dan Sastra, Yogyakarta: Naila Pustaka.
Janks, H. (2000). Domination, access, diversity and design: A synthesis for critical literacy education. Educational review, 52(2), 175-186.

Jones, S. (2013). Critical literacies in the making: Social class and identities in the early reading classroom. Journal of Early Childhood Literacy, 13(2), 197-224.

Jun-min, K. (2014). Critical literacy in the EFL classroom: Evolving multiple perspectives through learning tasks. Journal of Asia TEFL, 11(4), 109138.

Khoshnoud, K., \& Karbalaei, A. R. (2015). The Effect of Computer Assisted Language Learning (CALL) program on learning vocabulary among EFL left and right hemispheric dominant learners. European Online Journal of Natural and Social Sciences, 4(4), 761. Retrieved from www. european-science.com.

Ko, M. H. (2017). Learner perspectives regarding device type in technology-assisted language learning. Computer Assisted Language Learning, 30(8), 844-863. doi:10.1080/09588221.2017.1367310.

Kumagai, Y., \& Iwasaki, N. (2011). What it means to read "Critically" in a Japanese language classroom: Students' Perspectives. Critical Inquiry in Language Studies, $8(2)$, 125 152. doi:10.1080/15427587.2011.571277

Kurniawati, N. (2016). A Critical literacy program incorporated in a critical reading course at state Islamic university in Indonesia. (Unpublished doctoral's dissertation). Indonesia University of Education, Bandung, Indonesia.

Lamer, J. (2014). Do-it-yourself digital 3d storytelling. In Gura (Ed.), Teaching literacy in the digital age: Inspiration for all levels and literacies, Washington DC: International Society for Technology in Education.

Mei, B., Brown, G. T., \& Teo, T. (2018). Toward an understanding of preservice English as a Foreign Language teachers' acceptance of computer-assisted language learning 2.0 in the People's Republic of China. Journal of Educational Computing Research, 56(1), 74-104. doi:10.1177/0735633117700144

Meyer, E., \& Forester, L. (2015). Implementing studentproduced video projects in language courses: Guidelines and lessons learned. Die 
Unterrichtspraxis/Teaching German,48(2), 192210. Retrieved from https://www.jstor.org/stable/unteteacgerm.48.2.192

Naraghizadeh, M., \& Barimani, S. (2013). The effect of CALL on the vocabulary learning of Iranian EFL learners. Journal of Academic and Applied Studies, 3(8), 1-12. Retrieved from https://www.academia.edu/10432058/

Nassaji, H. (2015). Qualitative and descriptive research. Language Teaching Research, 19(2), 129-132.

Nourdad, N., Masoudi, S., \& Rahimali, P. (2018). The effect of higher order thinking skill instruction on EFL reading ability. International Journal of Applied Linguistics and English Literature, 7(3), 231-237.

Prins, E. (2017). Digital storytelling in adult education and family literacy: A case study from rural Ireland. Learning, Media and Technology, 42(3), 308-323. doi:10.1080/17439884.2016.1154075.

Shokrpour, N., Mirshekari, Z., \& Moslehi, S. (2019). Learning vocabulary electronically: Does computer assisted language learning (CALL) instruction have any impacts on Iranian EFL learners? Cogent Education, 6(1), 1-20. doi:10.1080/2331186x.2019.1702827.

Shor, I. (1999). What is critical literacy?. Journal of Pedagogy, Pluralism, and Practice, 1(4), 2-32.

Sung, E., \& Mayer, R. E. (2013). Online multimedia learning with mobile devices and desktop computers: An experimental test of Clark's methods-not-media hypothesis. Computers in Human Behavior, 29(3), 639-647.

Van Sluys, K., Lewison, M., \& Flint, A. S. (2006). Researching critical literacy: A critical study of analysis of classroom discourse. Journal of Literacy Research, 38(2), 197-233. doi:10.1207/s15548430jlr3802_4

Wallace, M. \& Wray, A. (2016). Critical reading and writing for postgraduates. California: Sage Publications Inc.

Wodak, P. \& Meyer, M. (2009). Method of Critical Discourse Analysis. London: Sage Publication. 